\title{
炭酸ガスレーザーを用いた選択的近位胃迷走神経遮断術 - - - 犬における長期減酸効果 - - -
}

\author{
Parietal cell vagotomy with $\mathrm{CO}_{2}$-laser in the dog \\ --acid reduction in long term follow up -- \\ ○門田俊夫, 三村一夫, 加辺純雄, 佐々木光一, 佐藤敬文 \\ 大崎裕子，玉能正悦 \\ Toshio Kadota, Kazuo Mimura, Sumio Kanabe, \\ Kouichi Sasaki, Takafumi Satou, Yuuko Ohsaki, \\ Shoetsu Tamakuma \\ 防衛医科大学校 外科学第一講座 \\ First Department of Surgery, National defense \\ Medical College
}

\section{ABSTRACT}

The peripheral nerve function is easily impared by carbon dioxide laser irradiation whereas the blood vessel is well preserved because $\mathrm{CO}_{2}$-laser is absorbed by water and loses its energy. On the basis of this concept, the adequate irradiation of $\mathrm{CO}_{2}$-laser defocused beam was carried out on the gastric wall from the serosal surface. In the irradiated area, the vagus nerve was destroyed but blood vessels were preserved $\left(\mathrm{CO}_{2}\right.$-laser vagotomy). In order to demonstrate the efficacy of this procedure, acid reduction test was performed in 5 dogs after $\mathrm{CO}_{2}$-laser vagotomy for 6 months. Gastric wall blood vessels were also compared between $\mathrm{CO}_{2}$-laser and parietal cell vagotomy with making plastic cast. The following conclusions were obtained: 1) Vagotomy effect was well preserved up to 6 months period in the dog. 2) Gastric blood vessel stracture was well preserved in $\mathrm{CO}_{2}$-laser vagotomy group.

I 諸 言

炭酸ガスレーザーを生体組織に照射するると，末 梢神経柱比較的感受性が高く，容易化変性するが 血管などの水分含量の多い組織では、レーザーエ ネルギーが水に吸取されるため，影留を受けにく く, 組織は温存される。乙の特性を利用した, 炭 酸ガスレーザーの臨床応用研究の一環として, 我 々は㟶酸ガスレーザーを用いた, 選択的近位胃迷 走神経遮糸術を開発し，その有用性につき報告し
でたてれは，従来の選択的近位胃迷走神経切 離術(以下選近迷切) と異索り, 炭酸カスレーザ

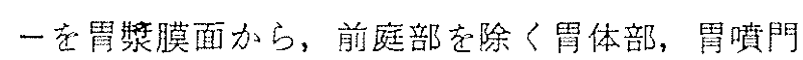
部に照射することにより，血流を温存しつつ，迷 走神経を遮断する術式で，手技が簡単で，手術時 間は短かく，亲た零粘膜血流が温存されるため， 防卸機構が保持されるなどの利点を有している。

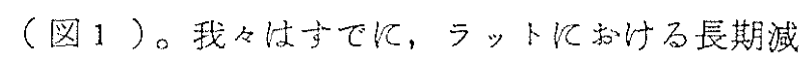
酸効果を检討したが，今回留の形態や迷走神経分 布がより人間に近いと言われる、イヌにっいて， 


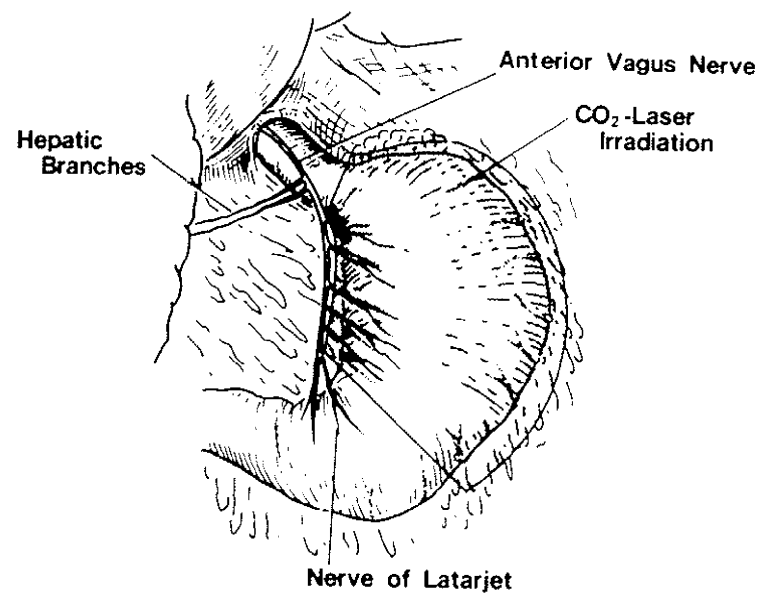

図 1 炭酸ガスレーザーによる選规的近位胃 迷走神経遮断術

レーザー迷切を試み，その照射条件と，長期減酸 効果について検討した。また，イヌに通常の選近 迷切とレーザー迷切を行ない, 直後の胃壁血管構 築の温存性を、ブラスチック鋳型模型を作製して 観察した。

\section{II 対象と方法}

検討には雑種成犬体重約 $15 \mathrm{~kg}$ 用いた。使用し た機種は，日本赤外線株式会社製炭酸ガスレーザ ーメス, Model-60。Handpieceには, 標準タイプ の $=100 \mathrm{~mm}$ 用的。非焦点照射の条件は，焦点 から胃漿膜照射面までの距離を（非焦点距離）を 100mm，その時の照射面でのスポット径壮約 $10 \mathrm{~m}$ 。 移動速度を, 毎秒 $1 \mathrm{~cm}$ の連続照射で行った。出力 は20ワットの格子状 2 回照射を行った。方法はヶ

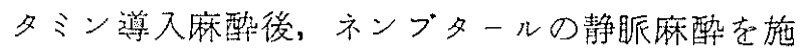
し, 霄を露出したのち, 図 1 に示す様に, 前庭部 を除いた，胃喷聞，体部前後壁に，均一に照射し た。幽門形成術は行わず，そのまま闒腹した。

IIIレーザー迷切後 6 力月までの減酸効果

奏験 1 として，雑種成犬 5 匹走用い，迷切前 に, まず,ペンタガストリン刺激試験を行っ た。方法は24時間絶食後に, ケタミンとネンプタ ールで麻酸し，胃管を揮入して胃内を十分な注射
用蒸留水で洗浄し，ペンタカストリンを $7.5 \mu g / \mathrm{kg}$ 筋注し，15分ごとに投与後60分去で胃管から霄液 を採取し，乙の酸度を測定して，最高酸分泌量 ( MAO) と最大酸分泌量 (PAO) 算出した。次 いで開腹後レーザー迷切を施行し，閉腹した。そ の後通常のドッグフードで飼育を続け, 術後1カ 月， 2 力月， 3 力月， 6 力月後の減酸効果を，同 様のペンタガストリン刺澈試験で測定した。その 結果, $\mathrm{MAO}$ は 1 力月目飞 $5.57 \pm 2.71 \mathrm{mEq} / \mathrm{h}$, $\mathrm{PAO}$ 的 $1.82 \pm 0.72 \mathrm{mEq} / \mathrm{h}$ 。 2 力月目 $\mathrm{K}, \mathrm{MAO}$ $7.06 \pm 3.99, \mathrm{PAO} 2.53 \pm 1.30$ 。3 カ月目にはMAO $5.34 \pm 4.49, \mathrm{PAO} 2.39 \pm 1.70$ 。6 ケ月目には $\mathrm{M}$ $\mathrm{AO} 2.75 \pm 1.85, \mathrm{PAO} 1.29 \pm 1.04$ と， 6 力月目ま での長期減酸飞良好宗結果が得られた（図 $2 ， 3$ )。

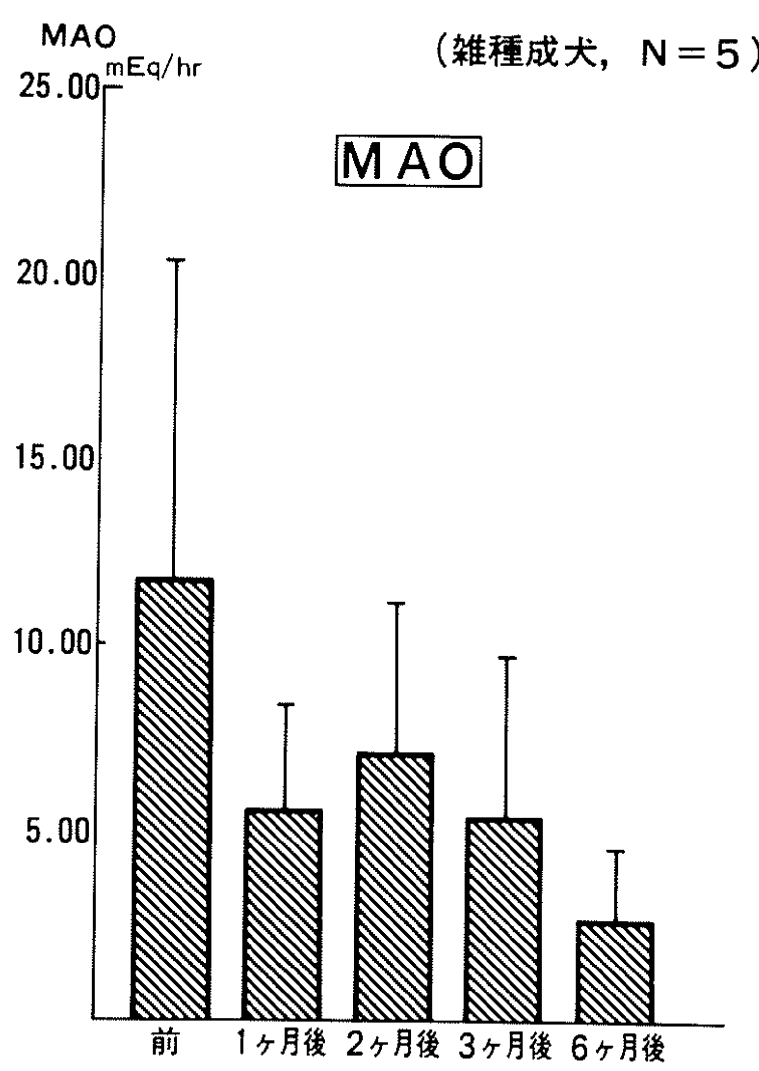

図2 レーザー迷切の減酸効果 
（雑種成犬， N=5）
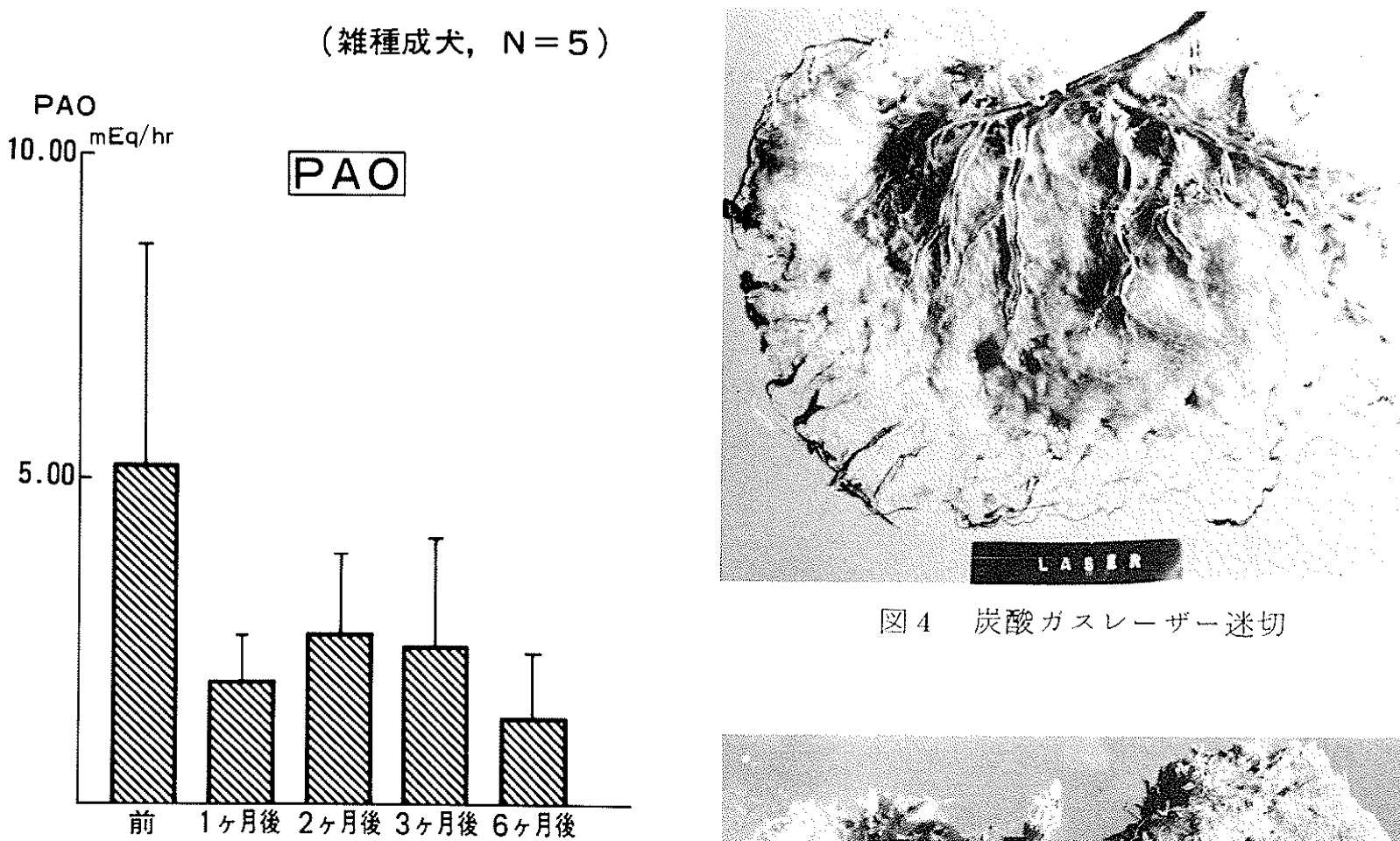

図 4 燹酸カスレーザ一迷切

図 3 レーザー迷切の減酸効果

IV レーザー迷切後の帠壁血管構築

レーザー迷切の利点の一つである胃壁血管構㐐

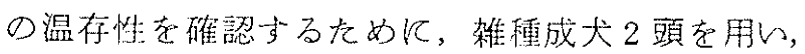
それぞれにレーザー迷切と選切迷切を行ん，ブラ スチック血管滖型を作賴して血管構筑の相諱を調 べた。選近迷切は，レーザー迷切の垻合と同様の

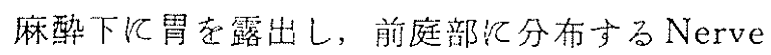
of Latarjet 蕰存して, 霄体部および噴門部に分 布する迷走神経枝を，小整得そって，血管ととも

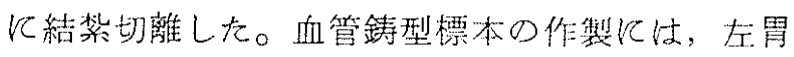

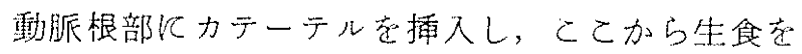
注入して，胃壁行分布する血管加的液莒十分洗 净してから, メルコックх®注入して, 固定し, これを水酸化ナトリウム液に入れて，周囲組織を 融解し，血管鋳型を作製した。琵体部，喷門部に 分布する血管は，レーザー迷切走行った犬では十 分温存され，選近迷切荙行った犬では，正常索血

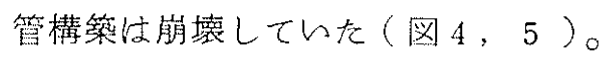

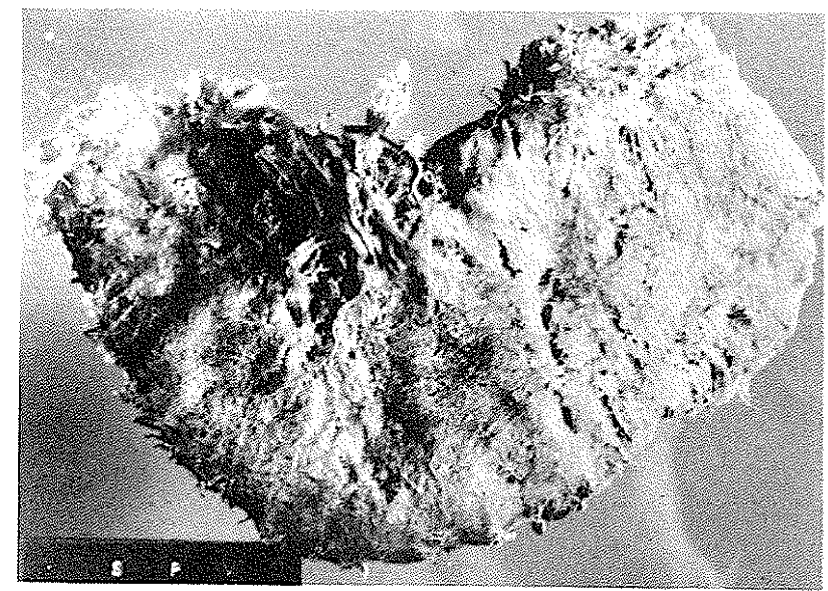

図 5 選近迷切

$V$ 若 祭

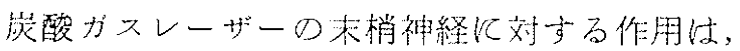
1973年に Schreiber らによって報告されている1) が，我々も動物実験によって，栄酸ガスレーザー の非焦点照射が来梢神経の变性作用莒起とかとと を確認している2)。一方，炭酸ガスレーザーは， 水に吸収されやすく，水分に富光組織では，在と んど深部に達し得度い。この2つの特性芫利用し

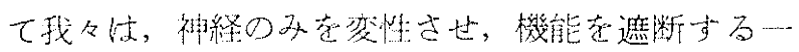
方, 血流恤存する, 新しん炭酸ガスレーザー苍用いた

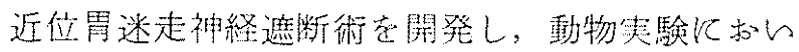

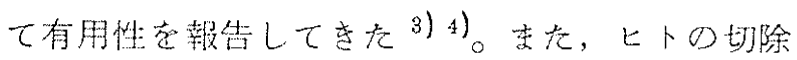
值前の䑁芫用いて，ヒトの胃に和けるレーザー迷 
切の効果を, 神経の麥性と, 血管の温存性の両面 加組織学的《検討した ${ }^{5)}$ 。乙の血管の温存性は, 近年特に注目されている胃粘膜防御機構とも, 密 接に関連しており，レーザー迷切の最大の利点の 一つである。この血管構築の温存性に関しては, 今回の犬におけるレーザー迷切と選近迷切の, メ ルコックス樹脂模型の比較で, 肉眼的飞も著明な 差を認めた。さらに, 迷走神経遮断あるいは切離 術老議論する際, 迷切直後もさるとと疗がら, 長 期にわたって減酸効果が維持される事が重要であ る。ラットに和ける長期減酸効果については，す でに報告しているが，ヒトの胃により近いイヌの 胃を用い, ペンタガストリン刺激試験を行い, 現 在までに，6力月までの減酸効果を確認した。

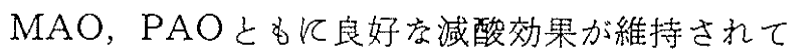
おり，乙の段階で，迷走神経の再生㹥認められな い。しかし, 検討したイヌ 5 頭中の 1 頭には， 24 時間の緦食にもかかわらず,ペンタガストリン刺 激試験前の胃内洗浄で，食物残督を認める例があ り, レーザー迷切時に, 前庭部のNerve of Latarjet の一部まで照射が及んだ可能性が示唆された。 今後は, 前庭部の非照射部の保護に, 一層の完壁 さが要求されると思われる。さらに又, これらの イ又の減酸効果を, 12 力あるい梳, 数年単位で 追跡してゅくととと，小彎飞そった，脂肪層が比 較的曆い部飞対する，照射むらを減少させるとと も，今後の検討課題である。

\section{Il 結 論}

1）炭酸ガスレーザーを, 出力 20 ワット, 非焦点 距離 100 Tan，スポッ卜径約 10 man，移動速度每秒 10 Imの連続照射で，犬の胃の漿膜面に，格子状に 2 回非焦点照射する事に上る, 迷走神経遮断術を行 ot。

2) 乙の条件下において，プラスチック樹脂を用 いた血管構築の検討ては, 従来の選択的近位胃迷 走神経遮断術に比較し、レーザー迷切では著明な 構造変化党認めな加っ。

3）ペンタガストリン刺激試験を用いた検討では,
レーザー迷切を施行したイヌで， 6 力月までの長 期減酸効果が確認された。

诅文献

1) Schreiber, Von., Oswald, H. und Danz, M. : Experimentelle Untersuchung über Lasereffekte am peripheren markhaltigen Nerven. Z. Exper.

Chirung., 6:256, 1973.

2) Mimura, K., Kadota, T., Kanabe, S., et al: An Experimental study of selective proximal gastric vagotomy with carbon dioxide laser, J. Natl. Def. Coll. $7: 176,1982$

3）門田俊夫, 三村一夫, 岩佐 博, 他: 炭酸力 スレーザーによる選択的迷走神経切離術のラ ッ卜胃粘膜隇酸初果の研究. 日消外会誌, $16: 431,1983$.

4）門田俊夫，高濱素秀：炭酸ガスレーザーを用 いたラッ卜選択的近位胃迷走神経切離術の研 究, 第 2 報, 埼医大誌, $10: 221,1983$.

5）門田俊夫, 三村一夫, 加辺純雄, 他：岸酸力 スレーザーを用いた選択的近位胃迷走神経切 離術の臨床への試み，日本レーザー医会誌， $5: 569,1985$. 